\title{
STUDY OF EFFECTS OF TEMPERATURE AND RESIDENCE TIME ON CALORIFIC VALUE OF TORREFIED BIOMASS
}

\author{
Niranjan Bastakoti ${ }^{1}$, Harish Chandra Dhital ${ }^{2}$, Amrit Aryal $^{3}$ \\ ${ }^{1}$ Lecturer, Department of Mechanical Engineering, Kathmandu University, Kavre, Nepal \\ ${ }^{2}$ Engineer, Nepal Electricity Authority, Kathmandu, Nepal \\ ${ }^{3}$ Lecturer, Department of Mechanical Engineering, Institute of Engineering, Kathmandu, Nepal
}

\begin{abstract}
In developing counties, biomass is a major source of residential energy. In the past, biomass in its unprocessed form was used for cooking and heating. Commercial purpose has been limited due to low heating value of biomass. Many attempts, regarding improvement of energy density have been made in recent times for biomass technology. Due to which process such as pyrolysis are invented for achieving increased efficiency and calorific value of unprocessed biomass by removing water content and volatile organic compounds from unprocessed raw biofuel. Torrefaction is a biomass energy densification process where unprocessed biomass is heated $\left(200^{\circ} \mathrm{C}-300^{\circ} \mathrm{C}\right)$ removing water content and volatile organic compounds (VOCs) from them and making them denser in energy. Torrefaction is a relatively new subject where many researches have been done to examine its potential in biofuel energy densification and biofuel development. This paper presents a work of unprocessed biomass torrefaction process performed on Institute of Engineering Biomass Laboratory. The goal of the research was to study effect of residence time and temperature on torrefaction process along with its mass yield (ratio of torrefied mass to initial mass) on dry and ash free basis. For the process, mixed sawdust was used as biomass which was subjected to temperatures $210^{\circ} \mathrm{C}, 240^{\circ} \mathrm{C}$ and $270^{\circ} \mathrm{C}$ at 15,30 and 45 minutes residence times, in inert atmosphere of nitrogen to produce torrefied biomass. Results from the research showed calorific value increase with increasing both temperature and residence time, effect of temperature being more prominent. Highest calorific value was found to be $5454 \mathrm{cal} / \mathrm{g}$ at $270^{\circ} \mathrm{C}$ and 15 minutes residence time. The biofuel thus obtained can be further briquetted to increase energy density.
\end{abstract}

Keywords: Torrefaction, Mild Pyrolysis, Calorific Value, Energy Density ***

\section{INTRODUCTION}

Biomass energy is one of the major sources of energy all over the world and also in Nepal. Biomass is used extensively for cooking and heating purposes with some industrial applications as well. Utilization of biomass has always been limited to household uses like cooking and heating. This is because of low heating value of biomass compared to coal and other fossil fuels. Transportation and storage of loose biomass has been difficult because for same value of energy biomass is required in large amounts than fossil fuels.

Biomass is normally considered as low grade energy. When used in raw form major portion of energy released during combustion biomass is spent in combusting volatile organic compounds (VOCs) and removing water content (moisture). These constituents reduce energy output from biomass. Burning of biomass for cooking in rural areas produce indoor air pollution, which is a major problem causing health effects especially on women and children who are exposed more to the polluted gas. Biomass upgrading processes like Pyrolysis and Torrefaction can both upgrade biomass energy state causing energy densification and also reducing pollution. These upgrading processes when applied can improve state of biomass and make it useful.

History of torrefaction goes back a long way. Torrefaction derives its name from a traditional process of roasting coffee beans which makes them brittle and gives distinctive flavor. Charcoal makers have always known this substance and most likely that it was used by blacksmiths to reduce iron and obtain primitive steel [1]. First work in wood torrefaction was reported in France in $1930^{\text {ee }}$ s to produce a gasifier fuel [2]. Torrefaction process has also been used historically as a reducing agent in metallurgical process. Most of the research in Torrefaction has been performed to examine effect of residence time and temperature on torrefaction process. One of the researches was done by Bergman (2005b) [3]. Grotheim (2008) also carried out the research for effect of temperature and residence time on torrefaction process [4]. The biomass used was corn stover.

Torrefaction of unprocessed biomass can be described as a thermo chemical conversion process where biomass in raw form is heated typically between $200-300{ }^{\circ} \mathrm{C}$ in an inert atmosphere, preferably by supplying nitrogen gas. Biomass undergoes changes in its physical and chemical composition 
during torrefaction. Moisture and volatiles are removed leaving behind energy dense biomass referred as torrefied biomass. The process may be called mild pyrolysis, with removal of smoke producing compounds and formation of solid product, retaining approximately $70 \%$ of the initial weight and $80-90 \%$ of the original energy content [5].

Torrefaction increases calorific value of unprocessed biomass. In addition, torrefied biomass has other properties like hydrophobicity and grindability. These properties make torrefied biomass suitable as a better fuel with good quality for combustion and gasification applications [6].

\section{MATERIALS AND METHODS}

Muffle furnace, Oxygen bomb calorimeter, Gas regulator with hose, Digital weighing machine, and Nitrogen and oxygen gas were required during torrefaction process and its heating value calculation. Equipment setup consisted of nitrogen gas cylinder connected to hot air oven through a hose pipe with regulator. Flue gases were allowed to escape through outlet in hot air oven. Heating rate of the oven was maintained at $10^{\circ} \mathrm{C}$ per minute. Nitrogen gas was supplied to create inert atmosphere. Inside oven, biomass to be torrefied was kept in aluminum trays. Digital weighing machine was used to weigh biomass to precision.

\subsection{Muffle Furnace}

A muffle furnace is a front loading box-type oven or kiln for low as well as high temperature applications such as to determine what proportion of sample is non- combustible, fusing glass and heat treatment of metals. Specification of muffle furnace is NUTRONICS PMTC-3040.

\subsection{Bomb Calorimeter}

It is a constant volume calorimeter which is used in measuring the heat of combustion (calorific value) of a particular reaction. Bomb calorimeters can withstand large pressure (30-40 bars) within them. Electric spark is used to ignite the fuel, as the fuel burns, it heats up the surrounding air, which expands and escape through the tube. Convection loss from the surface of bomb and escaped air is responsible for heating the water surrounding the bomb. Bomb calorimeter which we used during our research is 1108 Oxygen Bomb from Parr Company.

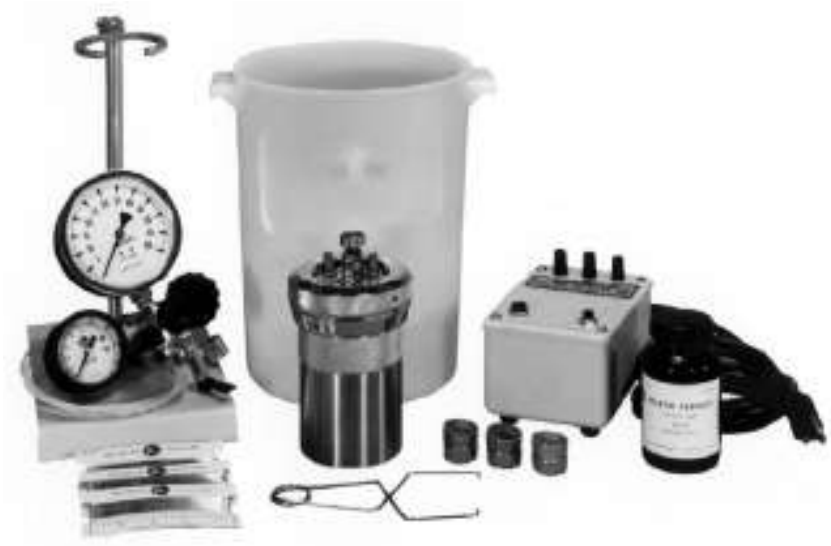

Fig -1: Different parts of oxygen bomb calorimeter

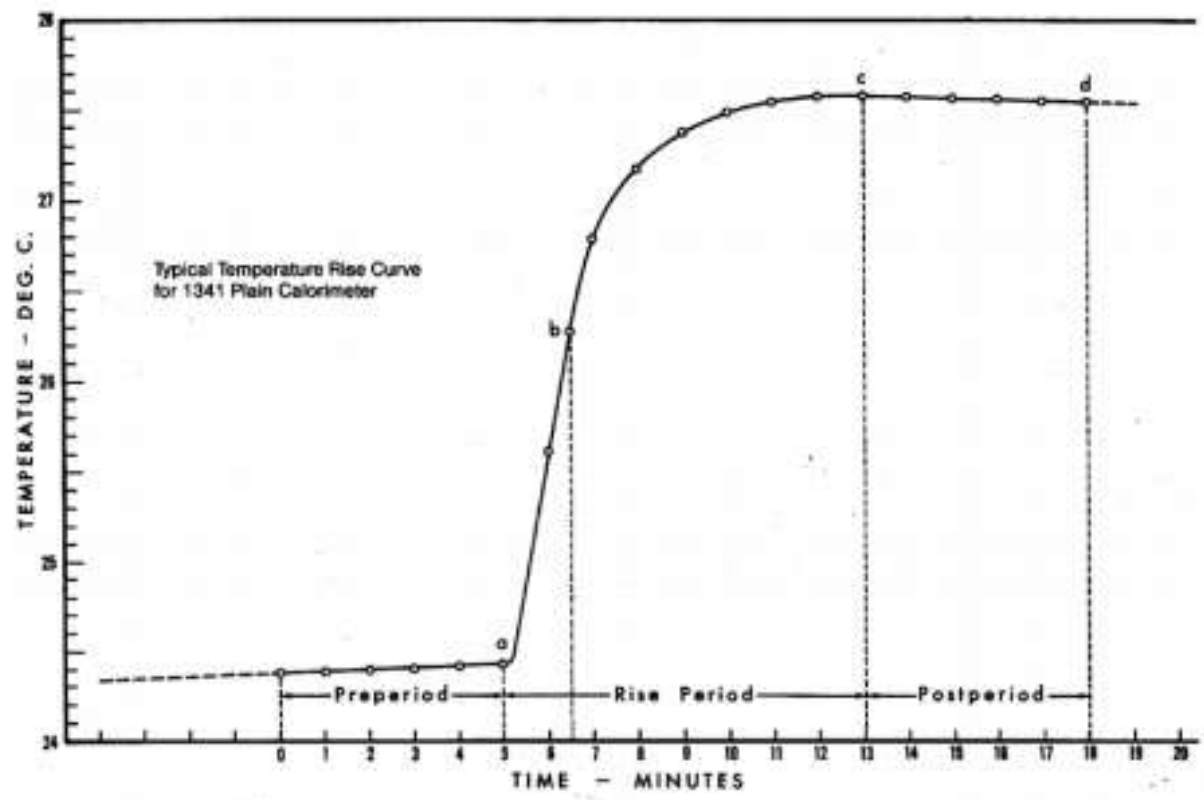

Fig -2: Typical temperature vs. time graph for oxygen bomb calorimeter 


\subsection{Gas Regulator with Hose Pipe}

The primary functions of gas regulator are reducing the high pressure gas in the cylinder or the process line to lower pressure to a piece of equipment. It is not flow control device. It is used to control deliver pressure only. Hose pipe is a flexible pipe which is used to carry gas, liquid.

\subsection{Digital Weighing Machine}

It is a high accuracy weighing machine available in market. It is used to measure mass at certain degree of precision and accuracy. Its least count was 0.01 grams. Maximum weight measure by machine is 200 grams. Manufacturer of the machine is ADAM SCALES AND BALANCES.

\subsection{Equipment Setup}

Regulator with hose pipe was connected to nitrogen gas cylinder. The other end of the hose was connected to oven through a cork. Nitrogen gas was passed through the hose pipe to create inert atmosphere in the oven. Inside the oven mass to be torrefied was kept in alumunium trays. There was one port on the other side in oven for outlet of flue gases. Oven contained a thermometer operated through a sensor to regulate and maintain temperature of oven. Least count of hot air oven's thermometer was $1^{\circ} \mathrm{C}$ and that of bomb calorimeter was $0.02^{\circ} \mathrm{C}$.

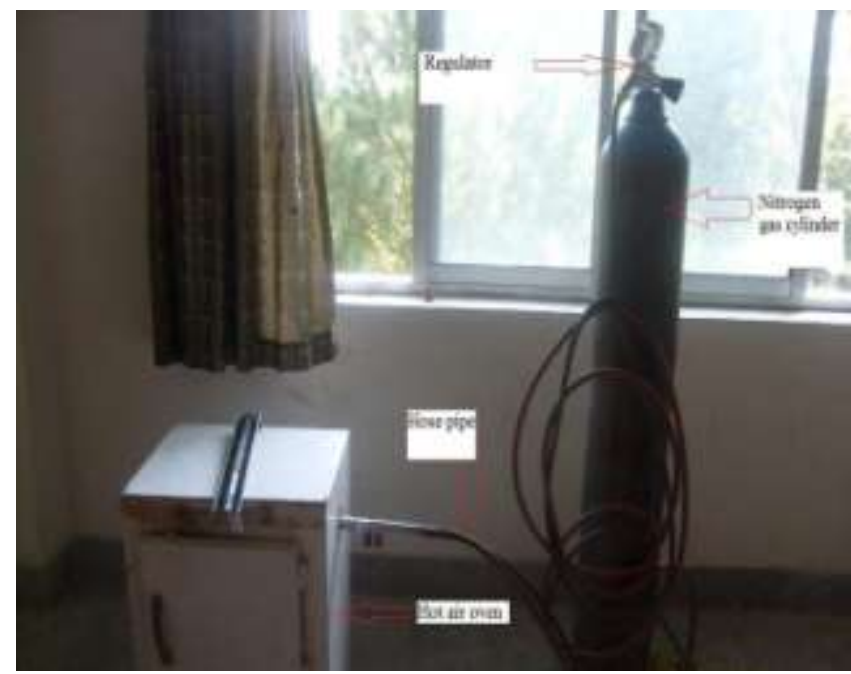

Fig -3: Equipment setup for the experiment

Torrefaction was carried out at temperatures $210^{\circ} \mathrm{C}, 240^{\circ} \mathrm{C}$ and $270^{\circ} \mathrm{C}$ at 15,30 and 45 minutes residence times for each temperature. Heating value of these nine samples was calculated using oxygen bomb calorimeter. For each sample three calculations were performed. Mass loss analysis was performed by comparing initial mass to final mass and calculating percentage mass loss.

\section{RESULTS AND DISCUSSION}

Proximate analysis is carried out according to British Standard to test energy properties of biomass and it's suitability for briquetting. The averaged final result is given in Table -1. Proximate analysis aims at determining water content, volatile content, ash and carbon content of the biomass. Volatile organic compounds (VOCs) consist of permanent gases like $\mathrm{CH}_{4}, \mathrm{CO}_{2}, \mathrm{~N}_{2}$, methanol, $\mathrm{CO}$ and vapor among which $\mathrm{CH}_{4}, \mathrm{CO}$ and methanol are combustible fuel which form the bio-oil after condensation.

Table 1: Results of proximate analysis of sawdust sample

\begin{tabular}{|l|l|l|l|l|}
\hline Biomass & Moisture & VOCs & Ash & Carbon \\
\hline $\begin{array}{l}\text { Sawdust } \\
\text { (mixed) }\end{array}$ & $17.00 \%$ & $67.44 \%$ & $2.70 \%$ & $12.86 \%$ \\
\hline
\end{tabular}

Standard ASTM Test methods were applied to calculate calorific value for the sawdust samples. The final results are given in Table -2 . Each calorific value given in Table -2 is averaged value for ten identical samples torrefied under identical conditions. Fig -4 shows a temperature vs. time graph for oxygen bomb calorimeter from experiment. This graph is essential in calculation of calorific value. The graph is satisfactorily similar to theoretical graph that should be obtained as shown in Fig -2.

Table 2: Averaged calorific value at different conditions of temperature and residence time

\begin{tabular}{|l|l|l|l|}
\hline S.N. & $\begin{array}{l}\text { Temperatur } \\
\text { e }\left({ }^{\circ} \mathrm{C}\right)\end{array}$ & $\begin{array}{l}\text { Residence } \\
\text { Time (min) }\end{array}$ & $\begin{array}{l}\text { Calorific } \\
\text { value (cal/g) }\end{array}$ \\
\hline 1 & 210 & 15 & 4284 \\
\hline 2 & 210 & 30 & 4277 \\
\hline 3 & 210 & 45 & 4295 \\
\hline 4 & 240 & 15 & 4914 \\
\hline 5 & 240 & 30 & 4924 \\
\hline 6 & 240 & 45 & 4710 \\
\hline 7 & 270 & 15 & 5454 \\
\hline 8 & 270 & 30 & 4683 \\
\hline 9 & 270 & 45 & 4544 \\
\hline
\end{tabular}




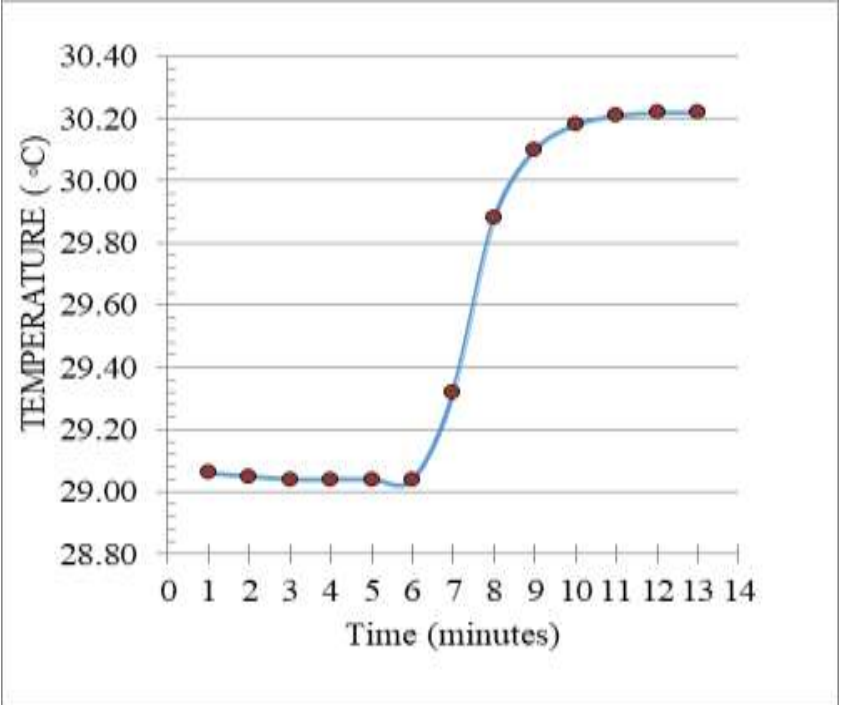

Fig -4: Typical temperature vs. time graph for oxygen bomb calorimeter from experiment

\subsection{Variation of Calorific Value with Temperature} at Constant Residence Time

From Fig -5, the highest calorific value was found to be $5454 \mathrm{cal} / \mathrm{g}$ at $270^{\circ} \mathrm{C}$ temperature and 15 minutes retention time. It was found that the calorific value rose with the increased temperature for 15 minutes retention time whereas the calorific value declined for 30 and 45 minutes retention time between temperature 240 and $270^{\circ} \mathrm{C}$. This was the result of more time availability for volatile combustible materials to fire and caused unwanted combustion of carbon content.

At lower temperatures and residence time, major portion of volatiles and moisture were removed which increased its calorific value but after long exposures at higher temperatures carbon content also started to get released due to which overall calorific value started decreasing.

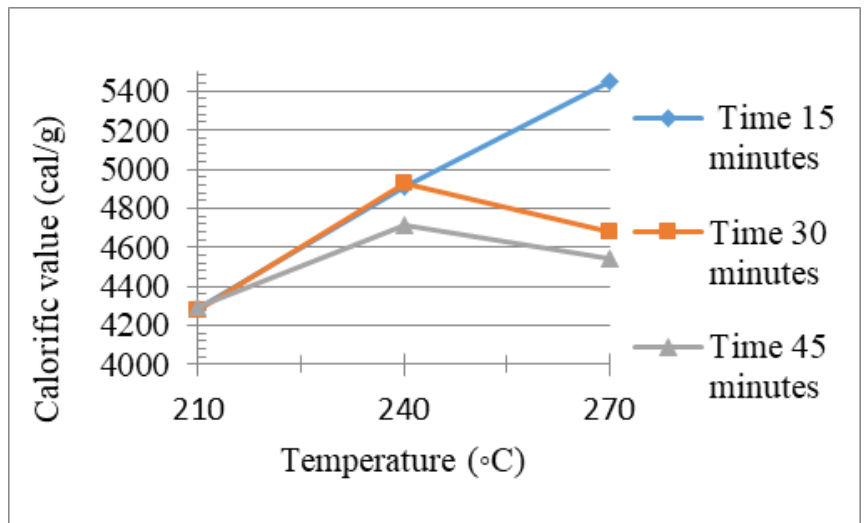

Fig 5: Change in calorific value with temperature at constant residence time

\subsection{Variation of Calorific Value with Residence}

\section{Time at Constant Temperature}

It can be observed from the Fig -6 that calorific value increased slightly with elevated retention time at $210^{\circ} \mathrm{C}$. Whereas in temperature between 240 and $270 \mathrm{oC}$ calorific value decreased after 30 minutes retention time. This decrease in calorific value is more for $270^{\circ} \mathrm{C}$.

From Fig -5 and Fig -6 it is observed that the effect of temperature is more significant than retention time in increasing calorific value of torrefied biomass. It can also be observed that at higher temperatures and longer residence time calorific value decreased. The optimum condition for torrefaction was $270^{\circ} \mathrm{C}$ temperature at 15 minutes retention time where the corresponding calorific value was calculated to be $5454 \mathrm{cal} / \mathrm{g}$.

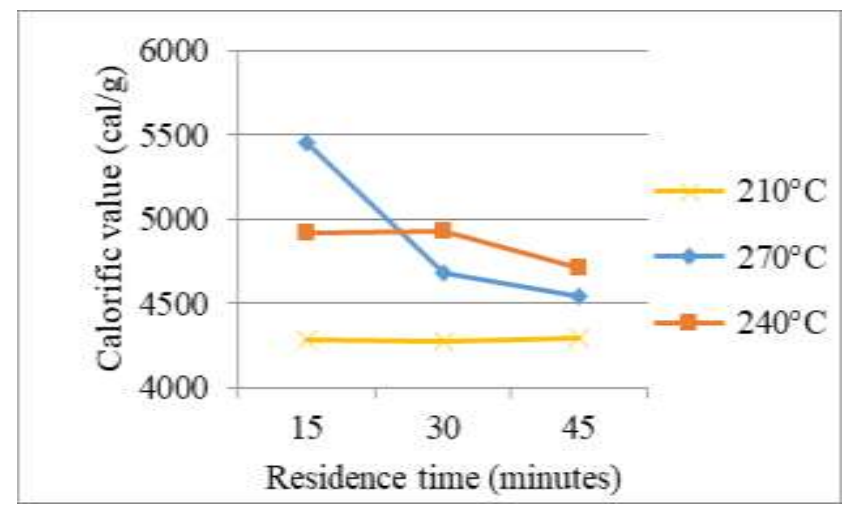

Fig 6: Change in calorific value with residence time at constant temperature

\subsection{Mass Loss with Residence Time at Constant}

\section{Temperature}

During the process, the biomass loses typically $20 \%$ of its mass. This results in energy densification of the torrefied biomass. Table -3 shows typical value of mass loss from sawdust sample during torrefaction process $\left(210^{\circ} \mathrm{C}\right.$ temperature)

Table 3: Mass loss from sawdust sample at different residence times at $210^{\circ} \mathrm{C}$ temperature

\begin{tabular}{|l|l|l|l|}
\hline Residence time & $15 \mathrm{~min}$ & $30 \mathrm{~min}$ & $45 \mathrm{~min}$ \\
\hline Initial weight & 4.00 & 4.00 & 4.00 \\
\hline Final weight & 3.27 & 3.23 & 3.08 \\
\hline Mass loss (\%) & 18.25 & 19.25 & 23.00 \\
\hline
\end{tabular}

From Fig -7 it is seen that mass loss increases slightly with increase in residence time at constant temperature. However percentage mass loss is high for higher temperatures. This is because according to science of torrefaction after temperature exceeds $200^{\circ} \mathrm{C}$ volatile materials start to get released from biomass. Higher release of volatiles occurs at 
higher temperature. Rate of mass loss from 30 to 45 minutes residence time is found to be lower for $270^{\circ} \mathrm{C}$ compared to $240^{\circ} \mathrm{C}$ and $210^{\circ} \mathrm{C}$. This is because almost all volatile organic compounds are eliminated at higher temperature $270^{\circ} \mathrm{C}$ at 15 minutes residence time which results in no increase in mass loss, practically.

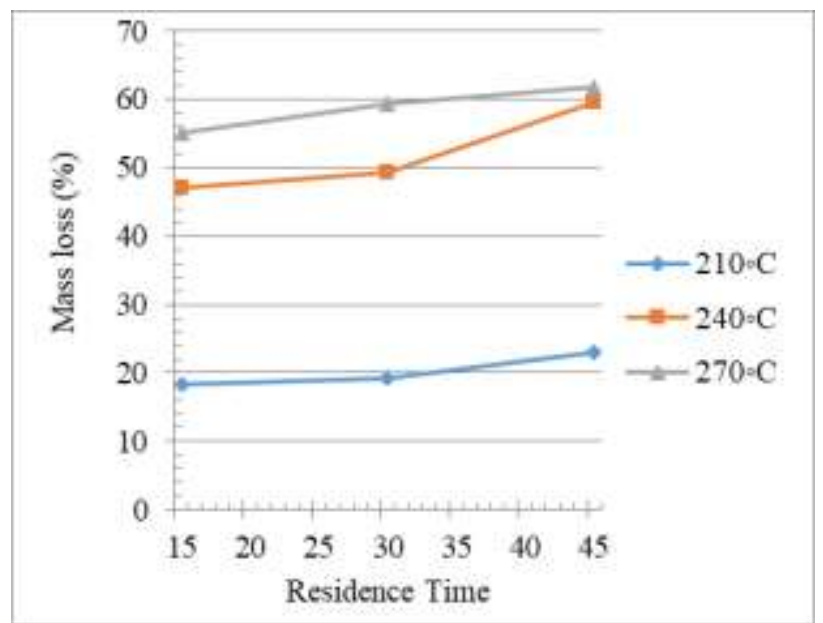

Fig 7: Mass loss for different temperatures and residence time

\section{CONCLUSION}

From the proximate analysis $12.86 \%$ of biomass consisted of combustible carbon content. Extraction of these combustible solid from biomass is the major challenge of the project. Numerous pyrolysis and carbonization processes are invented for these purpose. Amongst all of the these processes, torrefaction is the most efficient process. It is a relatively lower temperature process which requires less residence time. Although some energy is spent for combustion of unprocessed biomass, heating value is significantly increased.

Torrefaction of wood dust was done in the project. Sawdust was chosen as biomass sample for research because of its easy availability. Sawdust obtained from carpentry is already in powder form requiring no further grinding. After the completion of research, it was found that torrefaction process increased heating value of unprocessed biomass. The wood dust was experimented under various conditions of temperature and residence time to calculate the individual calorific values. Torrefaction at temperature $270^{\circ} \mathrm{C}$ and 15 minutes residence time was concluded to be the most suitable condition for the heating value. Calorific value obtained at this condition is $5454 \mathrm{cal} / \mathrm{g}$.

\section{ACKNOWLEDGEMENT}

The authors acknowledge support from Department of Mechanical Engineering, Department of Science and Humanities and Center for Energy Studies, Pulchowk Campus, Institute of Engineering, Tribhuvan University, Nepal and Department of Mechanical Engineering, School of Engineering, Kathmandu University.

\section{REFERENCES}

[1] Girard P and Shah N, 1991, Recent Developments on Torrefied Wood, An Alternative to Charcoal, for Reducing Deforestation, Food and agriculture organization of the United Nations (FAO), pp.101114.

[2] Bioenergy, 2000, A new process for Torrefied wood manufacturing, General Bioenergy, vol.2, No.4, (https://www.bioenergyupdate.com/magazine/securit y/NL0400/bioenergy update_april_2000.htm)

[3] Bergman P C A, Boersma A R, Zwart R W H and Kiel J H A, 2005, Development of Torrefaction for biomass co-firing in existing coal-fired power stations "biocoal", ECN Report, ECN-C-05-013

[4] Grotheim K, 2008, Milestone 1 report- Torrefaction and Densification of Biomass Fuels for Generating Electricity, Bepex, particle processing technology, December 8, 2008, US

[5] Arcate J R, New process for torrefied wood manufacturing. Bioenergy update. vol. 2, No. 4, April 2000 ,

(http:www.techtp.com/Bioenergy\%20Update\%20.pd f).

[6] Bergman P C A and Kiel J H A, Torrefaction for Biomass upgrading, Energy Research Centre of the Netherlands (ECN) Unit ECN Biomass, (www.ecn.nl/biomass).

\section{BIOGRAPHIES}

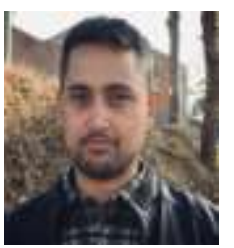

Mr. Niranjan Bastakoti is Lecturer at Department of Mechanical Engineering, School of Engineering, Kathmandu University. He graduated in Mechanical Engineering from Institute of Engineering, Tribhuvan University, Nepal and completed his Master's in Mechanical Engineering from Indian Institute of Technology, IIT Bombay. He is an energy technology consultant based in Kathmandu Nepal.

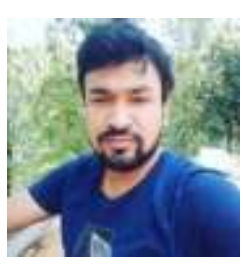

Mr. Harish Chandra Dhital is an Engineer at Nepal Electricity Authority. He graduated in Mechanical Engineering from Institute of Engineering, Tribhuvan University, Nepal and completed his Master's in Energy Systems Planning and Management from the same institute. He is a part time faculty at Institute of Engineering, Tribhuvan University.

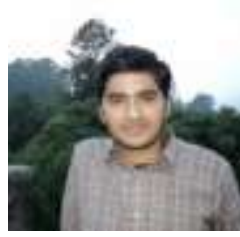

Mr. Amrit Aryal is an energy technology consultant and a part time faculty at Institute of Engineering, Tribhuvan University. He graduated in Mechanical Engineering from Institute of Engineering, Tribhuvan University, Nepal and completed his Master's from Shenyang Aerospace University, China. 